\title{
Interest Representation, Interest Alignment and the Role of Seeking Consensus in the Renewal Process of Hungarian State Management ${ }^{1}$
}

\author{
Csaba Lentner \\ Faculty of Political Sciences and Public Administration, National University of \\ Public Service; Hungary \\ lentner.csaba@uni-nke.hu \\ Bianka Parragh \\ Faculty of Political Sciences and Public Administration, National University of \\ Public Service; Hungary \\ parragh.bianka@uni-nke.hu
}

\section{ABSTRACT}

The interest representation of owners, employee participation and endeavours to achieve consensus can be identified as the operational factor of well-managed publicly owned companies in the renewal process of state management. Higher quality expectations that appear to arise in respect of public services and the higher quality standard expected of public sector employees in the course of the performance of their duties all point in the direction of achieving a well-functioning state. This study focuses on representing the interest of the state as an owner, the changes in the institutional system of interest alignment and the search for consensus, the development that has materialised over the past decades, its alternatives arising from the regulatory environment and the attitudes and motivations of economic actors affected by the trend in the Hungarian economic environment. The analysis highlights the balancing role of the state, which is becoming more prominent.

Keywords: state, owner's interest representation, lobbying, seeking consensus, labour relations, social dialogue

JEL: A12, E6, G01, H12, H83, I18, J45, J5

1 Research was conducted in the framework of the Operative Program for the Development of Public Administration and Public Service 2.1.2. - (Competitive Central Hungary Operative Program) VEKOP-15-2016 under the title 'Further development of the controls of public finances and state budget for good governance - in historic and international dynamics' (Wekerle Sándor Public Finances Academic Workshop). 


\section{Introduction}

The role of interest alignment and the search for consensus have appreciated in today's economic and social relations. On this intellectual horizon, a considerable emphasis is placed on participation that affects labour relations and the dimension of cooperation between social partners and the state. Responding to national level economic and social issues and interest harmonisation in conformity with EU regulations are crucial constituents of the stable operation of the state and sustainable development. The state is not merely a market regulator, but also an ever more crucial employer, given that the companies that provide community services are increasingly in national ownership.

The role of publicly owned companies in the economy is increasing in comparison to the situation in 2009 in terms of the competitiveness of the national economy of Hungary and the economic and social relations of the country. As part of the turn in the fiscal and the economic policy that started in $2010^{2}$, the state and municipalities organise the supply to residents and government instrumentalities through companies in their ownership in the case of natural monopolies (such as gas, electricity, water and waste) (Domokos et al., 2016, p. 193). In addition, highlighting the role of state-owned companies in the economy, more than $60 \%$ of the state-owned companies operate in a real competitive environment, under market conditions (Milicz, 2016, p. 220). All economic actors use their public services and consume the public goods produced by them and the goods that they produce under the competitive conditions of the market economy. In the market economy, it is the job of corporate management to achieve the best possible results by optimally combining input resources (raw materials, labour force). The classic requirement of the maximisation of profit is, however, replaced today by the ever more prominent role of the capabilities that enable the undertaking to continue. ${ }^{3}$ This means that all owners, employers and employees are interested equally in the continuous operation of the corporate organisation, thus the income from work and the sources of dividends can regenerate safely - if not maximally, then at least continuously. In addition, it is a fundamental social expectation that the public sphere should be characterised by the responsible management of public funds, operation with a view to profit and endeavours to be ever more efficient, including the operation of large state-owned corporations. Economic and financial transactions have costs and it is a key task of the business management to reduce these costs. It is necessary to set up an institutional and regulatory system that makes it possible to cut transactional costs. Dani Rodrik, a professor at Harvard,

2 For more detail see Veres \& György (2016).

3 Its corporate base is an enactment of the accounting principle of continued business. The ability of a business to go on. On the level of the national economy, this is about a sustainable budget in adherence to these concepts. A corporation whose operation is sustainable or expanding provides grounds for dividends to owners, bonuses to the management and income to employees. Masses of operable companies are the pledge of a prospering national economy. For more detail see Lentner (2015). 
characterised the group of institutions that are indispensable for economic and social growth as the focus of institutional thinking, in the course of which he identified institutions that guarantee the protection of title to property, institutions capable of handling market failures and addressing asymmetries in information, institutions that ensure stabilisation and institutions for legitimisation (Rodrik, 2000, 2003).

The topicality of institutional thinking has crucial importance in the economic relations of Hungary. The legitimacy of this economic orientation was substantiated by the financial and economic crisis in 2008-2009. One of the key fields in the process of institutionalisation is the strengthening and simultaneous restructuring of the role taken by the state employees' participation as an instrument for making the interest alignment processes more fruitful in terms of labour relations in the interest of efficient state management. State management means the entirety of the management, planning, controlling and regulatory practices and methodology over the formation of budgetary revenues and expenses of the public finances and assets in state ownership by the government. Within state management, the appreciation of the management, ownership and controlling aspects in the operation of state-owned companies has come to the foreground in Hungary. Thus, public finances comprise not only the formation of budgetary revenues and expenses, but also the operation of the assets in its ownership, as well as the regulatory environment that influences the operation of companies that are active in the public administrative sector of the country without being in state ownership.

With the model of the active state, the concentration of state assets has become more important (their re-purchase after privatisation or the entirety of the management methods applied here). The market cannot be left alone; economic issues can be understood together with their consequences. Institutions matter, as Douglas North (1993) expressed, straight to the point. By institutions, this economic school (Veblen, 1965; Hamilton, 1919; Commons, 1936) mean a factor that makes an impact on all economic decisions (statutes, state rules, informal rules, culture). In Hungary the institutionalisation of state management was initiated to achieve state operation that reacts well to negative external circumstances, fends off adverse effects and gives effective responses, breaking with the earlier superficial treatment of institutional issues, which Ronald Coase, Nobel Prize winning British economist also found problematic (Coase, 1937, 1991).

This study examines the system of interest representation in the labour market, which strengthened when the role undertaken by the state after the 2007-2008 crisis became more prominent, with a focus on Hungary. It is a key goal of the study to trace the tendencies of the system of interest representation after the political turn and to compare the state characterising the period after the crisis to the era before the crisis. It is the goal of the paper to show the trend of the labour market relations becoming better regulated 
and simultaneously more seamless by the more comprehensive ownership role taken by the state in the labour market and as a consequence of active regulation and control with the result that in the labour market, the conditions for the long-term cooperation between market actors came into existence.

\section{The Basic Relationships Between Interest Alignment, Labour Relations and Participation}

\subsection{Theoretical Background in the Context of Concepts}

The process of interest alignment means the quasi-labour relations between the employer and employees on the corporate level, in which the state and the interest representative system play the role of a catalyst and coordinator. The scope of this category is expanded by the state being a market participant itself $F^{4}$, therefore its function is not narrowed down to just coordination between the company and the employees as an economic governmental function. The state also needs revenues to perform its tasks to operate the state and social responsibilities, its tasks to give aid and support and to maintain institutions. Through the budget the state taps the resources needed to maintain its operation from earners of revenues or income (corporations, employees) through revenue centralisation institutions. The determination of the rates, ratios and shares depends on lobbying by corporations and employees and on the interest advocacy of corporations and labour markets, which is 'confronted' with the lobbying ability and strength of the state's willpower. Through the channels and processes of seeking consensus, they have to find the optimal level of their needs and the ways to satisfy their needs. Confrontation and mutual damaging are in the interest of neither the parties nor the whole of the economy. Several aspects of reciprocity appears in the parties' relations.

In this extremely complex system, it is crucial to recognise the values and significance of the human factor. Nowadays it is a general expectation of employees to be well prepared, creative, ready to accept new responsibilities, adaptive, inquiring, motivated, and flexible. Simultaneously, employees' expectations of their workplaces have changed, as they find development, promotion, continuous learning and training, and self-fulfilment extremely important (Parragh, 2010, p. 169). In the process of seeking consensus, conflict treatment and resolution, the state therefore plays a balancing role in respect of the relations between employers and employees.

The interest representation and lobbying of the state as an owner is of key importance in the expectations of successful operation of publicly owned corporations. In the interest of successful, efficient, economical and socially recognised operation, it has become necessary to place the role of the state

4 Based on 'Governmental finances and private finances come closer than ever to each other' (Parragh, 2015). 
as an owner, the representative functions and management roles in the context of the market. A complex approach is indispensable in the consistent renewal of leadership and management roles with a view to finally restructuring the motivation on a system level, which manifests itself in the responsible management of national and public assets.

The creation of good governance and the ever more complete achievement of the integrity of public life, place the concept of interest representation into a new dimension linked to integrity in comparison to how it was earlier, with the help of institutions and related legal regulatory frameworks to be set up in the new approach. Thus as a new approach, lobbying centred on integrity is closely linked to the conceptual system of integrity. ${ }^{5}$

The weakening of the operation of the neoliberal market economy and its ever more disputed principles from the aspect of efficiency and sustainability makes the active role undertaken by the state prominent. The strengthening of the role of the state as an owner and the strengthening of importance of the publicly financed institutions that conform to the rules of budgetary management leads to the expansion of the employment responsibilities of the state as the owner of corporations and public utilities and the operator of publicly financed institutions. Consequently, the state as an employer has an ever-stronger presence in the labour market.

It is a global level UN initiative to support and intensify cooperation between the economy and other social groups. ${ }^{6}$ Thus, in the course of corporate operation, the protection of human rights becomes more prominent and therefore the combatting of corruption and the protection of work, social and environmental standards. The supreme corporate value ${ }^{7}$ is a combination of added value and profitability, sustainable financial management and the protection of corporate assets.

- On the market side, a successful corporation has a passion for its customers. ${ }^{8}$ In its operation, it serves innovation, creativity and social development. It respects staff and endeavours to cooperate with its partners involved in interest representation. It accepts responsibility for the environment and undertakes social responsibility. ' The term of undertaking responsibility and the realisation of social development extends over a longer period. The constituents of a successful and

5 For more detail, see Dávid \& Lóczi's work (2013). Vocational Ethic and Culture, Lobbying, National University of Public Service, 2013.

6 Global Compact values. In addition to the UN, the OECD and the ILO also support these values. UN Global Compact (UNGC): The annual research of the UNGC gives a comprehensive overview of how businesses of various sizes align their operation strategies and practices to sustainable principles.

7 Superior Value - Core corporate values superior to any other.

8 Passion for our Customers - The emphasis is more on customer contentment, retention and increasing their loyalty in the interest of long-term cooperation and trust.

9 Corporate Social Responsibility. For more detail of the requirements for the enactment of internal synergies that become more prominent instead of supporting groups outside the company see Lentner (2013). 
efficient corporate management philosophy are long-term thinking, a strategic approach, responsible thinking and a long-range perspective, which appears as a basic need in respect of all economic actors.' (Parragh, 2015)

- In terms of corporate operation in a market context, the state ensures the 'preservation and increase of public wealth, responsible and costsaving utilisation and the application of public funds, high standard (public) services and products that are affordable and sustainable to the satisfaction of the public' (Domokos et al., 2016, p. 198).

The two participants of the labour market, the employer and the employee, represent somewhat different interests however, due to goals that are different from the start. ${ }^{10}$ In the classical approach, it is the primary interest of the employer to maximise profit. In contrast, employees are motivated to maximise the income earned from their work and to enjoy appropriate circumstances at work. Both sides do their best to make their criteria come true. The main point of interest alignment is to resolve these 'conflicts' and harmonise interest and possibilities. The system ${ }^{11}$ of labour relations within a corporation helps to ease the conflict of interests between the two sides and resolve these conflicting interests, which only meant bipartite relations ${ }^{12}$ between social partners at first. Nowadays, tripartite relations between social partners and the state are typical. ${ }^{13}$

\subsection{The Hungarian Aspect of Labour Relations, Participation}

In Hungary the concept of interest representation gained a particular meaning in the science of sociology, by which all institutions of labour relations were termed at the time of the political turn. By labour relations, we mean the institutional relations between employees, employers and representative and interest representative organs and the institutional relationships they have with the state (governmental instrumentalities).

The foundation of labour relations is the objectively existing difference in interests between the world of work and capital, which is bridged by employment. From another approach, the base is the relationship between the employer and the employee in which the vital interests ${ }^{14}$ of the company also have a role. The outcome of the relationship can be cooperation or conflicting interest, interest harmonisation or dispute. However, the purpose of labour

10 However, it is our basic concept that safe and sustainable operation is the common interest of a business and the employees. This is profit and salary that is acceptable for both sides and job and business retention.

11 For more details on the system of labour relations than presented in this chapter see Kőmúves (2015).

12 Primary concept of labour relations: about the relations between social partners see Kömúves (2015).

13 A secondary concept of labour relations: the relation between social partners is complemented with state participation; the introduction of the secondary concept can be linked to the name of Kömüves (2015).

14 Understood for both the business and employees. 
relations is to seek consensus. As based on the definition of the concept by labour relations, we mean the system of institutional relations between employers and employees and their interest representative organisations, i.e. contractual and/or legally regulated relations, which are basically intended to sustain cooperation between participants, prevent conflicts as far as possible and resolve any already existing conflict. A good interest alignment system can give a competitive edge to employees on the labour market and to employers on the entrepreneurial market simultaneously.

To sum it up, the institutional system of labour relations is assisted by the system of collective bargaining and agreements, employee participation and amicable and pressurising instruments of labour conflicts and disputes. The national level negotiations and agreements with a view to determining the mainstream of the economy and social policy have an effect on the quality of labour relations. On the labour market taken in a narrow sense, in the scenario of employees and employer, the harmonising and interest alignment activity of the state and economic chambers help to resolve the existing asymmetry in power and the exertion of pressure ${ }^{15}$ notwithstanding formal equality.

\section{Effective Principles of Industrial Democracy Relying on Consensus - In Historical Contrast}

By the 'industrial democracy' approach, the authors mean the concentrated market of employers and employees, which is shaped by the rules of supply and demand. Nevertheless, in the period after the crisis, the state/ government exerted a stronger influence over tendencies in which interest representations have a coordinating role.

It is a pledge of our economic coming to the fore and social rise that Hungary finds the $21^{\text {st }}$ century model for rising to lead. This cannot be the same as the Anglo-Saxon free market model, nor can it be the post-WW2 European pure social market economy. As a rule, free market formation leads to crisis due to the regulatory weaknesses of the state, while the social market economy model loses competitiveness due to the high-level of income and social security. The two and a half decades following the political turn generated problems with economic growth and balance ${ }^{16}$. It was characterised by an extremely low level of employment, as well as tightening possibilities in the labour market and increased strain in the world of capital and work. According to Tobin and Buitner (1982), the underemployment of work and capital is sufficiently frequent and long-term that it justifies the need for intervention in the economic policy. Economic and social tensions are coupled with a worsening position for the population to advocate their interest

15 An area that needs to be reinterpreted: Employees do not necessarily need to be on the minus side and employers in a power surplus. A reverse situation is not out of the question, for example in the case of physicians, well-trained engineers, skilled labourers.

16 Based on certain thoughts of Matolcsy et al. (2008). 
and earn income. The trust of the society in leadership is shaken by international comparison, as illustrated in Figure 1.

Figure 1. Social distrust in the Hungarian government - international comparison, 2009

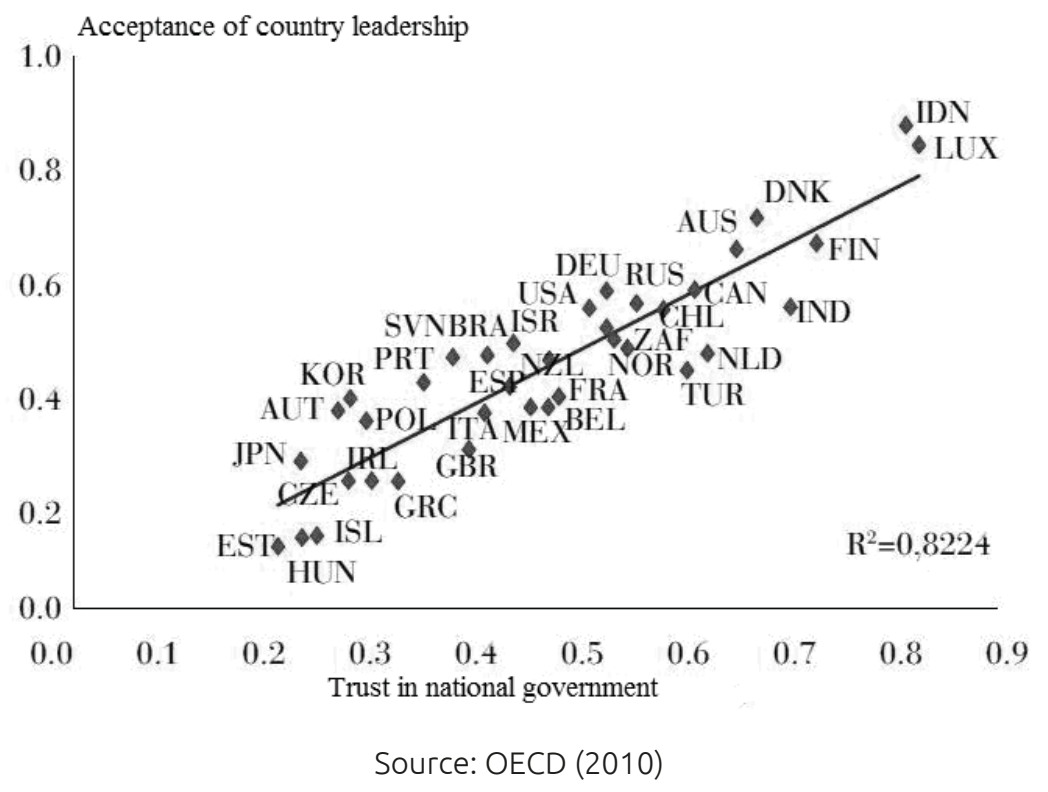

In Hungary, several social problems are associated with a high level of state redistribution and the ensuing low employment level. In the fields of domestic natural monopolies, former state monopolies were replaced by foreign private monopolies, thus no real competitive environment could come into existence. Employment fell victim to the structural problems of the labour market and in the relationship between employers and employees, the possibilities of advocacy in employee interests became limited. From 2010, increasing the number of jobs, the elimination of fiscal traps for public finances and families in households and economic growth were in focus. ${ }^{17}$ The instruments of economic influence, which is associated with an active state model, state regulation and control, manifested themselves in a sustainable budget and then economic improvement. The 'fruits' of all this is the restoration of the decency of work and the creation of new jobs, leading people living in social, territorial and professional seclusion back to the working environment, which eases the dependency of employees on employers, which strengthens their lobbying ability.

Expanding state resources, increasing the number of jobs, the expansion of effective demand and purchasing power, and state influence on the working environment all improve the conditions for working. Furthermore, the position of interest representation becomes easier as the social aspect

17 Its results taxonomic summary can be seen in Matolcsy (2015). 
of labour relations becomes more prominent. ${ }^{18}$ The methods and possibilities of interest advocacy between the participants in the labour market have become more harmonised. The positive trends are clearly shown in the 2013 data presented below in comparison with the data from 2008. The society trusts the government in Hungary more in CEE comparison as well, which is illustrated in Table 1.

Table 1. Classification of organisations according to the stage of strategic management development

\begin{tabular}{|l|c|c|c|c|c|c|}
\hline & $\begin{array}{c}\text { National } \\
\text { Parliament } \\
2013\end{array}$ & $\begin{array}{c}\text { Trust } \\
\text { Parliament } \\
\text { since 2008 }\end{array}$ & $\begin{array}{c}\text { National } \\
\text { Government } \\
2013\end{array}$ & $\begin{array}{c}\text { Trust } \\
\text { Government } \\
\text { since 2008 }\end{array}$ & $\begin{array}{c}\text { Trust } \\
\text { Political } \\
\text { Parties }\end{array}$ & $\begin{array}{c}\text { Political } \\
\text { Parties since } \\
2008\end{array}$ \\
\hline EU Average & $29 \%$ & $-7 \%$ & $29 \%$ & $-8 \%$ & $19 \%$ & $-3 \%$ \\
\hline $\begin{array}{l}\text { Central and } \\
\text { Eastern EU }\end{array}$ & $17 \%$ & $-3 \%$ & $22 \%$ & $-4 \%$ & $13 \%$ & $1 \%$ \\
\hline $\begin{array}{l}\text { Czech } \\
\text { Republic }\end{array}$ & $11 \%$ & $-5 \%$ & $13 \%$ & $-7 \%$ & $10 \%$ & $-2 \%$ \\
\hline Hungary & $29 \%$ & $13 \%$ & $31 \%$ & $13 \%$ & $20 \%$ & $12 \%$ \\
\hline Poland & $13 \%$ & $0 \%$ & $14 \%$ & $-5 \%$ & $10 \%$ & $3 \%$ \\
\hline Slovakia & $29 \%$ & $-12 \%$ & $29 \%$ & $-19 \%$ & $19 \%$ & $3 \%$ \\
\hline Slovenia & $6 \%$ & $-29 \%$ & $11 \%$ & $-25 \%$ & $5 \%$ & $-13 \%$ \\
\hline
\end{tabular}

The complete data line of Table 1 is available in the said source, also in European dimension.

Source: Eurobarometer 70.1 (2008) \& Eurobarometer 79.3 (2013), Public Integrity and Trust in Europe, 2015, Berlin

After 2010, the world of work plays a key role in building the society and economy and capital revenue is not a competitive alternative to work. In Hungarian life, strategy work, recognition at work and entrepreneurial success rank by far above community, recreational values and individual selfexpression. In addition to financial reasons, people therefore chose to work even in their spare time because they desire to be successful financially. The active presence of the state in the labour market and the labour relations between employees and employers improved the success of interest reconciliation.

\section{An Effective System of Social Dialogue in Hungary}

In the conciliatory forum that started in 1989 in Hungary with the establishment of the National Interest Reconciliation Council, a tripartite regime (trade union, employers, government) and then, from 2004, a bilateral conciliatory regime was in place. In this system, the government only took part with the right of consultation, enacting the concept of the neoliberal government to withdraw from influencing the economy and the operation of market participants.

In Hungary, the regulatory bases of operation on a statutory level are created in a consultative body so that the cost efficiency and representation of wider

18 The classic contrast between capital and work (which can be described by Marxist attributes) is less sharp. 
social layers can be achieved. Thus, the new body can consult on the directions of national policy and the aspects of these directions that are capable of influencing the economy and the society.

It is a fundamental expectation of EU member states to maintain social dialogue. In 1997 in the course of the Amsterdam amendment to the Treaty of Rome, the Agreement on Social Policy originally attached to the Maastricht Treaty finally became part of the Treaty of Rome. Under Article 1 of the Agreement on Social Policy, it is the objective of the member states to promote dialogue between social partners.

The highest-level forum of the institutional system of social dialogue, which is the present procedure for economic interest alignment, is regulated by Act XCIII of 2011 on the National Economic and Social Council ('Council'), its organisation and operation. The purpose of the act is to assist the formation of an advisory board with consultative power that discusses general economic and social policy issues affecting the whole of society instead of central coordination conciliation forums ${ }^{19}$ whose functions overlap in many cases and which operated side-by-side. This advisory board helps to make the most important economic and social political decision with its recommendations, rulings, analysis and opinions.

With the establishment of the Council in 2011, the new consultation mechanism provides a wider scope of possibility for social dialogue than before. The Council is a body for consultation, recommendations and giving advice operating independently of Parliament and the government that was established to discuss the comprehensive issues that affect the development of the economy and society, national strategies reaching over governmental terms and to promote the development and implementation of harmonic and balanced economic growth and appropriate social models. Its members are the interest representative organisations of employers and employees, economic chambers, civil organisations active in the area of national policy, representatives of sciences and arts from Hungary and across the border and churches.

The tasks of the National Economic and Social Council are manifold. Within the scope of its tasks to consult, comment and recommend, it monitors and analyses the social and economic development of the country ${ }^{20}$. The mission of the body is to discuss national issues that affect the comprehensive development of the economy and society and national strategies reaching over government terms that arise in the wake of such issues and to promote the development and implementation of harmonic and balanced economic

19 A detailed description of the former system can be found in Judit Lux's paper (2003).

20 For example in 2013, the Council adopted a ruling on the release of Hungary from the excessive deficit procedure against Hungary. In the opinion of László Parragh, the incumbent chair, it was 'the first ruling based on consensus that the council accepted'. This means that the release of Hungary from the procedure was in the interest of the whole of society, on which all five sides of the Council agreed. 
growth and appropriate social models. The primary goal of interest representation is to promote and protect the interests of employees related to employment and defend their interests.

\section{Conclusion}

This study set the objective to analyse the system of interest representation in the labour market, which strengthened as the role undertaken by the state became more prominent after the crisis in 2007-2008. It has been shown that among the process of transformation in the period following the political turn in Hungary, the issue of lobbying occupied an important area, which underwent several phases of development before it reached its present form. It is essential to ensure interest harmonisation in line with the EU regulations, in the framework of which the cooperation of interest representative organisations and employees must become dominant in addition to the stable operation of the state, foreseeable corporate finances and the simultaneous improvement of the financial situation of households based on mutual effects - ideas that have been justified in the structural unity of the theme of this paper.

Focusing on Hungary, it was a key question of the study to follow the tendencies of the system of interest representation after the political turn and to compare the state characterising the period after the crisis to the era before the crisis, which was answered in detail in the study.

It has been the main goal of the paper to show that the labour market relations have become better regulated and simultaneously more seamless thanks to the more comprehensive ownership role taken by the state in the labour market and as a result of active relation and control, with the result that in the labour market the conditions for long-term cooperation between market actors came into existence. An important result of the study is that the higher quality expectations that appear in the provision of public services point towards the achievement of good governance and the renewal of state management, in the course of which trend, a search for consensus, interest alignment and advocacy are indispensable.

It can be seen from the change in the more intensive role of the state that followed the period of crisis in 2007-2008 that effective and institutional conditions for social dialogue help labour relations to operate transparently and efficiently. In Hungary, the institutional conditions that enable and can implement effective social dialogue that addresses and considers the challenges of our age have become an indispensable constituent of long-term sustainable social and economic growth. 
Prof. Dr. Csaba Lentner is an university professor at the Faculty of Political Sciences and Public Administration of the National University of Public Service, the head of the Institute of Public Finance. He is an honorary professor at Szent István University and a private tutor at the University of Kaposvár. He was involved in research in Cambridge, at Sorbonne, at the Minzu University in Beijing, at the National University of Zhytomyr, in the Bank of England and in the Washington headquarters of the Federal Reserve. In 2013, he was awarded the Wekerle Sándor Academic Life Achievement Award for his pioneer activity in the interest of Hungarian finance and economic sciences. In 2016, the Hungarian Bank Association gave him the honorary title of Ambassador of Financial Culture for his work to create a new type of financial approach and scientific taxonomy.

His fields of research: state financial management, economic policy, bank regulation

Dr. Bianka Parragh, PhD, is an assistant professor at the Faculty of Political Sciences and Public Administration of the National University of Public Service, Institute of Public Management and Administration (and the Keleti Károly Faculty of Economics of the Óbuda University, Institute of Business and Management). She obtained a degree in economics in 2001 at the Faculty of Economics of the University of West Hungary and in 2004 she obtained a complementary degree in economic law at the Faculty of Economics of the University of Miskolc. She received a PhD degree in Business and Management in the Széchenyi István Doctorate School of the University of West Hungary in 2010.

Her fields of research: fiscal and monetary policy, competitiveness, economic policy, economic governance and interest representation. 
Interest Representation, Interest Alignment and the Role of Seeking Consensus in the Renewal Process of Hungarian State Management

\section{References}

Berke, G., \& Kiss, G. (2012). Commentary to the Labour Code. Complex Publishing House.

Coase, R. H. (1937). The nature of the firm. Economica, New Series, 4(16), 386405. doi: 10.1111/j.1468-0335.1937.tb00002.x

Coase, R. H. (1991). The institutional structure of production. Prize Lecture. Prize in Economic Scineces in Memory of Alfred Nobel, December 9, 1991. Journal des Économistes et des Études Humaines, 4(2), 431-439. doi: 10.1515/jeeh-1991-0401

Commons, J. R. (1936). Institutional economics. The American Economic Review, 26(1), 237-249.

Domokos, L., Várpalotai, V., Jakovácz, K., Németh, E., Makkai, M., \& Horváth, M. (2016). Renewal of Public Management. Public Finance Quarterly, 61(2). 178-198.

Eurobarometer 70.1 (2008) \& Eurobarometer 79.3 (2013). Public integrity and trust in Europe, Trust in national institutions. Berlin: European Research Centre for Anti-Corruption and State-Building (ERCAS).

György, L., \& Veress, J. (2016). The Hungarian economic policy model after 2010. Public Finance Quarterly, 61(3), 360-381.

Hamilton, W. H. (1919). The institutional approach of economic theory. American Economic Review, 9(1), 309-318.

Kőműves, Z. (2015). System of labour relations. Budapest: HVDSZ 2000 Publisher.

Lentner, C. (2013). Academic taxonomy and history of development of bank regulation. In C. Lentner (Ed.), Bank Management - Bank Regulation - Financial Consumer Protection (pp. 27-86). Budapest: National Public Service and Schoolbook Publisher.

Lentner, C. (2015). Economic, taxonomic and legal basis of the operation of the Hungarian national economy - with the presentation of unorthodox instruments of the bank of issue, In C. Lentner (Ed.), Fiscal finance and public fund management (pp. 31-76). National University of Public Service.

Lux, J. (2013). From the National Interest Alignment Council to the National Interest Alignment Council. Szemlélet - Társadalomkritikai és Kulturális Folyóirat [Consciousness - Social Critic and Cultural Journal], April 2003.

Matolcsy, G. et al. (2008). Renewed liberal and social market economy in Hungary. Budapest: Hungarian Growth Research Institute.

Milicz, A. (2016). Market role of the state and possibilities to control this role at public enterprises. Public Finance Quarterly, 61(2), 199-223.

North, D. C. (1993). The new institutional economics and development (Essay). St. Louis: Washington University. Available at http://econpapers.repec.org/ paper/wpawuwpeh/9309002.htm

OECD. (2010). Distrust in the Hungarian government - an international comparison, 2009.

Parragh, B. (2010). New challenges in human strategy: Crisis and reality. In M. Losoncz \& C. Szigeti (Eds.), During crisis, before upturn, Volume for Gyula Kautz Memorial Conference. Győr SZE GTK.

Parragh, B. (2015). Alteration of view in the public sphere - reform and competitiveness. In A. Csiszárik-Kocsír (Ed.), Business development in the $21^{\text {st }}$ century (pp. 375-392). Óbuda University. 
Rodrik, D. (2000). Trade policy reform as institutional reform. (Paper prepared for a Handbook on Developing countries and the next round of WTO negotiations edited by P. B. Hoekman). Harvard University. Available at https://ideas.repec.org/p/idb/brikps/8750.html

Rodrik, D., \& Subramarian, A. (2003). The primacy of institutions. Finance and Development, 40(30), 31-34.

Tobin, J., \& Buitner, W. (1982). Fiscal and monetary policies, capital formation and economic activity, In J. Tobin, Essays in Economics, Vol. 3: Theory and policy. The MIT Press.

Veblen, T. (1970). Theory of the leisure class (Hungarian translation). Budapest: Economic and Legal Publisher. 
POVZETEK

\subsection{Strokovni članek}

\section{Zastopanje in usklajevanje interesov ter vloga iskanja konsenza v procesu prenove upravljanja države na Madžarskem*}

Zastopanje interesov lastnikov, udeležbo in prizadevanja zaposlenih za dosego konsenza je mogoče opredeliti kot operativni dejavnik dobro vodenih podjetij v javni lasti v procesu prenove upravljanja države. Večja pričakovanja glede kakovosti, ki so se pojavila v zvezi z javnimi storitvami, in višji standard kakovosti, ki se pričakuje od zaposlenih v javnem sektorju v času opravljanja dolžnosti, kažejo v smer doseganja dobro delujoče države. Študija se osredotoča na zastopanje interesov države kot lastnika, spremembe v institucionalnem sistemu usklajevanja interesov in iskanje konsenza, razvoj v zadnjih desetletjih, možne alternative, ki izhajajo iz zakonodajnega okolja, in odnose ter motivacijo gospodarskih subjektov, na katere vpliva trend v madžarskem gospodarskem okolju. Raziskava izpostavlja usklajevalno vlogo države, ki postaja vse izrazitejša.

\footnotetext{
* Raziskava je bila izvedena v okviru Operativnega programa za razvoj javne uprave in javne službe 2.1.2 (konkurenčni osrednjemadžarski operativni program) VEKOP-15-2016 z naslovom »Nadaljnji razvoj nadzora nad dobrim upravljanjem javnih financ in državnega proračuna - v zgodovinski in mednarodni dinamiki« (akademska delavnica na temo javnih financ, Wekerle Sándor).
} 